\title{
Pengaruh Covid-19 terhadap Minat Belajar Daring Mahasiswa
}

\author{
${ }^{1}$ Muhamad habib, ${ }^{2}$ Eclisia Sulistyowati, ${ }^{3}$ Safitri Nur Rohmah, ${ }^{4}$ Ary Rachman Haryadi \\ ${ }^{1}$ Ilmu Hukum/fakultas Hukum dan Bisnis, Universitas Duta Bangsa Surakarta \\ Email Korespondensi: muhamadhabib58@gmail.com
}

\begin{abstract}
Abstrak. Wabah Corona merupakan penyakit yang berasal dari Tiongkok yang menyebar dengan cepat ke seluruh dunia. Virus tersebut dengan nama resmi COVID-19 menyebar di Indonesia pada awal Maret 2020. Penyebaran virus ini menyebabkan kerugian untuk banyak negara terutama dalam bidang ekonomi dan pendidikan. Dalam bidang pendidikan, COVID-19 juga mengubah model pembelajaran secara drastis; seluruh kegiatan pembelajaran dilakukan secara daring mulai dari tingkat sekolah dasar sampai perguruan tinggi. Penelitian ini merupakan penelitian diskriptif kualitatif yang mendeskripsikan kegiatan pembelajaran daring di Universitas Duta Bangsa Surakarta setelah ditetapkannya seluruh kegiatan pembelajaran dilaksanakan di rumah. Subjek terdiri dari 4 mahasiswa Universitas Duta Bangsa Surakarta. Pengumpulan data menggunakan angket yang dibagikan kepada mahasiswa. Berdasarkan hasil angket tersebut, kegiatan pembelajaran dengan mode daring di Universitas Duta bangsa surakarta sudah efektif dengan memanfaatkan aplikasi E-Leaarnig UDB, Zoom, Google Classroom, Schoology, Whatsapp dan Edmodo. Kendala dalam pelaksanaan pembelajaran daring yaitu masalah koneksi internet yang kurang mendukung dan keterbatasan kuota internet dari mahasiswa.
\end{abstract}

Kata kunci: Pengaruh; Covid 19; Minat Belajar Daring

Abstract. Corona outbreak is a disease originating from China that spread rapidly throughout the world. The virus with the official name COVID-19 spread in Indonesia in early March 2020. The spread of this virus caused losses to many countries, especially in the economic and educational fields. In the field of education, COVID-19 also changed the learning model drastically; all learning activities are carried out online starting from elementary school level to university level. This research is a qualitative descriptive study describing online learning activities at the University of Duta Bangsa Surakarta after the stipulation of all learning activities carried out at home. The subjects consisted of 4 students at Duta Bangsa Surakarta University. Data collection uses a questionnaire that is distributed to students. Based on the results of the questionnaire, learning activities with online mode at Universitas Duta Bangsa Surakarta have been effective by utilizing the E-Leaarnig UDB, Zoom, Google Classroom, Schoology, Whatsapp and Edmodo applications. Constraints in implementing online learning are internet connection problems that are less supportive and limited internet quota from students.

Keywords: Influence; Covid 19; Interest in Online Learning.

\section{PENDAHULUAN}

Wabah corona yang awal mulanya merebak di Negara dengan julukan Tirai bambu menyebar hingga ke berbagai negara, salah satunya adalah Indonesia. Pandemi yang sedang melanda negeri ini tentunya memberikan imbas ke berbagai bidang, seperti bidang ekonomi, sosial, dan terutama bidang pendidikan.

Penyebaran virus dari hewan ke manusia jarang terjadi, tetapi hal ini yang terjadi pada COVID-19, SARS, dan MERS. Manusia dapat tertular virus corona melalui kontak langsung dengan hewan yang terjangkit virus ini. Cara penyebarannya disebut transmisi zoonosis.
Beberapa hal yang harus dilakukan dalam pencegahan virus ini yaitu menjaga kebersihan tangan menggunakan hand sanitizer jika tangan tidak terlihat kotor atau jika tangan terlihat kotor cuci tangan dengan sabun, menghindari menyentuh mata, mulut dan hidung ketika sudah berinteraksi dengan orang lain, melakukan etika batuk atau bersin dengan benar yaitu menutup hidung dan mulut dengan lengan atas bagian dalam atau tisu, kemudian buanglah tisu ke tempat sampah, pakailah masker medis jika memiliki gejala pernapasan yang tidak normal dan melakukan kebersihan tangan setelah membuang masker, menjaga jarak minimal 1 meter dari orang yang 
mengalami gejala gangguan pernapasan (beritasumbar.com, 2020).

Menteri pendidikan mengeluarkan Surat Edaran Nomor 3 Tahun $2 \mathrm{O} 2 \mathrm{O}$ Tentang Pencegahan Corona Virus Disease (COVID19) Pada Satuan Pendidikan yang menyatakan bahwa meliburkan sekolah dan perguruan tinggi (Peraturan Pemerinatah,2020). Hal ini dilakukan untuk memutus mata rantai penyebaran COVID-19, yang berdampak terhadap dunia pendidikan yang ada dimanapun. Bagaimana dengan pendidikan Nasional?

Perguruan tinggi banyak yang ditutup pada akibat pandemi Covid-19, memberikan berbagai dampak pada mahasiswa, seperti penelitian Cao et al., (2020) menyebutkan bahwa Covid-19 berimbas pada ekonomi dan kehidupan sehari-hari termasuk aktivitas akademik. Di Depok, Jawa barat Tidak berselang lama setelah tersebar kabar ada warga yang terpapar Corona, gubernur DKI Jakarta Anies Baswedan membuat edaran agar seluruh lembaga pendidikan di DKI Jakarta diliburkan (beritasumbar.com,2020). menjadikan lembaga pendidikan diliburkan maka pembelajaran dengan menggunakan sistem online atau daring, yaitu belajar jarak jauh dari rumah masing-masing. sebagai pengganti kegiatan pembelajaran yang dilakukan secara online untuk semua jenjang pendidikan. Universitas Duta Bangsa surakarta merupakan salah satu perguruan tinggi yang menerapakan kebijakan tersebut.

Kebijakan yang dibuat oleh pimpinan Universitas Duta Bangsa Surakarta ini dilakukan agar mengurangi grafik penyebaran COVID-19 yang semakin hari semakin bertambah angka kematian maupun yang tertular.

E-learning (pembelajaran online) meliputi berbagai aplikasi dan proses seperti computer-based learning, webbased learning, virtual classroom, virtual Schoology, virtual Zoom, dan aplikasi lainnya ( Dakwah,2017). Pada dasarnya kegiatan pembelajaran online ini dilakukan untuk mengganti kegiatan pembelajaran secara langsung (Rizqon Halal Syah Aji,2020). Haryono dalam Waryanto mengatakan Pembelajaran online sebenarnya memiliki beberapa kelemahan yakni membutuhkan banyak biaya, penggunaan jaringan internet membutuhkan infrastruktur yang memadai, komunikasi memalui internet terdapat berbagai kendala/kekurangan. Meskipun demikian pembelajaran online dapat dikatakan efektif apabila mahasiswa dapat mencapai tujuan pembelajaran dan mahasiswa aktif dengan adanya interaksi antara dosen dan mahasiswa dalam pembelajaran tersebut dan tidak berpusat kepada dosen saja. Merriam dalam Wicaksono menyampaiakan Salah satu ciri utama dari pembelajaran mahasiswa yang sangat menonjol adalah adanya kemampuan dan kemauan dalam proses belajar dengan mengarahkan sendiri proses pembelajaran sesuai dengan kebutuhan yang dia inginkan atau disebut juga sebagai self-directed learning atau kerap disingkat sebagai SDL (Wicaksono,2012).

Banyak manfaat menggunakan Pembelajaran Online. Keuntungan penggunaan pembelajaran online Antara lain pembelajaran bersifat mandiri dan interaktivitas yang tinggi, mampu meningkatkan tingkat ingatan, memberikan lebih banyak pengalaman belajar, dengan teks, video, audio dan animasi yang semuanya digunakan untuk menyampaikan informasi, dan dapat memberikan kemudahan menyampaikan, memperbarui, mengunduh informasi. Mahasiswa juga dapat mengirim komentar pada forum diskusi, memakai ruang chat. mengirim email kepada siswa lain, hingga link video conference untuk berkomunikasi langsung (Basori, 2017).

Pembelajaran online dapat diartikan sebagai suatu jaringan komputer yang saling terkoneksi dengan jaringan komputer lainnya ke seluruh penjuru dunia. Aplikasi e-learning ini dapat memfasilitasi aktivitas pelatihan dan pembelajaran maupun proses belajar mengajar secara formal maupun informal, selain juga memfasilitasi kegiatan dan komunitas pengguna media elektronik, seperti internet, intranet, CD-ROM, Video, DVD, televisi, HP, PDA, dan lain sebagainya (Darmawan, 2012). Dalam penerapan e-learning (pembelajaran online), dosen dan mahasiswa memiliki perannya masing-masing. Pemanfaatan 
teknologi untuk model pembelajaran ini terutama dalam membantu dosen dan mahasiswa terutama pada pengelolaan kegiatan pembelajaran (Arnesti, 2015). Dosen memiliki peran sebagai fasilitator dan pembimbing dalam kegiatan pembelajaran, sedangkan mahasiswa memiliki peran sebagai konstruktor pengetahuan, pembelajar mandiri (independent learners), dan pemecah masalah (problem solvers) Bintaro \& Kusir dalam Maudiarti (Maudiarti,2018). Di samping itu, istilah E-learning (pembelajaran online) meliputi berbagai aplikasi dan proses seperti computer-based learning, webbased learning, virtual classroom, virtual Schoology, virtual Zoom, dan aplikasi lainnya. Kegiatan pembelajaran online ini dilakukan untuk mengganti kegiatan pembelajaran secara langsung.

Minat belajar mahasiswa dalam mengikuti perkuliahan merupakan sesuatu yang penting dalam kelancaran proses perkuliahan. Mahasiswa yang mempunyai minat belajar tinggi dapat menunjang proses perkuliahan akan semakin baik, begitupun sebaliknya minat belajar mahasiswa rendah maka kualitas perkuliahan akan menurun.

Berdasarkan hal tersebut peneliti ingin meneliti bagaimana dampak COVID-19 terhadap minat belajar daring di Universitas Duta Bangsa Surakarta.

Adapun rumusan masalahnya dalam penelitian ini adalah:

1. Bagaimana pengaruh pembelajaran daring terhadap minat belajar mahasiswa Universitas Duta Bangsa.

2. Apa dampak minat belajar mahasiswa Universitas Duta Bangsa ketika harus belajar dari rumah.

Penelitian ini dimaksudkan untuk mengetahui fenomena yang terjadi ketika pembelajaran daring yang dialami oleh setiap mahasiswa efektif atau tidak, lebih banyak ilmu yang diserap atau tidak, lebih antusias pembelajaran konvensional atau daring, berjalan lancar atau tidak.

Berdasarkan rumusan masalah tersebut maka ada variabel yang digunakan dalam penilaian yaitu variabel dependen nya adalah Minat belajar (Y). Sedangkan variabel independen adalah Pengaruh pembelajaran daring.

\section{METODE PENELITIAN}

Penelitian ini menggunakan metode deskriptif kualitatif. Penelitian kualitatif Merupakan penelitian yang digunakan untuk meneliti kondisi objek yang alamiah dimana peneliti sebagai instrumen kunci dan hasil penelitiannya lebih menekankan makna dari pada generalisasi atau Penelitian yang berlandaskan filsafat post positivisme (Ericha Windhiyana Pratiwi, 2020). Penelitian deskriptif merupakan penelitian yang dilakukan untuk mendeskripsikan suatu variabel, baik satu variabel atau lebih (independen) tanpa membuat perbandingan, atau menghubungkan variabel satu dengan variabel lainnya (Rizqon Halal Syah Aji, 2020). Di dalam penelitian ini, data yang dikumpulkan berupa kalimat dan penjabaran jawaban dari subjek yang dilakukan dengan angket. Pengambilan subjek menggunakan metode snowball throwing. Subjek terdiri dari 4 mahasiswa. Instrumen penelitian terdiri dari peneliti sebagai instrumen utama dengan instrumen bantu. Data dalam penelitian ini berupa angket online melalui WhatsApp yang merupakan jawaban dari subjek merupakan deskripsi dari pengaruh COVID-19 terhadap minat belajar mahasiswa perguruan tinggi Universitas Duta Bangsa Surakarta

Berikut pedoman wawancara yang digunakan:

1. Seperti apa teknis pelaksanaan pembelajaran daring ketika terjadinya pandemik COVID-19?

2. Aplikasi apa yang digunakan dosen untuk melaksanakan kegiatan pembelajaran online?

3. Bagaimana pelaksanaan pembelajaran online dengan menggunakan aplikasi yang ada?

4. Kendala Apa yang dihadapi ketika pembelajaran Online?

Sedangkan wawancara kepada mahasisiwa 1 dalam pelaksanaan kegiatan pembelajaran online sudah efektif karena kegiatan pembelajaran berjalan dengan baik meskipun koneksi internet kurang mendukung sehingga terdapat beberapa informasi yang 
kurang jelas diterima, akan tetapi apabila informasi kurang jelas mahasiswa diminta untuk bertanya dan dosen akan menjelaskan kembali materi yang disampaikan. Mahasiswa 2, mahasiswa 3 dan mahasiswa 4 tidak jauh berbeda pendapatnya dengan mahasiswa 1 .

\section{HASIL DAN PEMBAHASAN}

Hasil penelitian menunjukkan bahwa pembelajaran yang dilaksanakan di Universitas Duta Bangsa Surakarta semenjak adanya virus COVID-19 yaitu belajar dari rumah masing-maswing dengan menggunakan sistem pembelajaran online. Menurut mahasiswa 1 sistem pembelajaran online sudah efektif. Kegiatan pembelajaran online berjalan dengan baik dan menyenangkan meskipun terdapat suatu kendala dalam situasi dan kondisi keadaan lingkungan rumah atau jaringan (signal) maka dapat menghambat mahasiswa yang koneksi internetnya lamban dan keterbatasan pada kuota internet, selain itu perkuliahan dengan sistem yang tidak berubah atau dengan pola perkuliahan yang sama secara terus menerus yang mengakibatkan kebosanan dan informasi yang kurang jelas sehingga mahasiswa terganggu dalam memahami materi yang diberikan dosen. Aplikasi yang digunakan untuk mata kuliah yang diambilnya menggunakan E-learning $U D B$, whasapp, google classroom, telegram, gmeet. Berikut cuplikan wawancara 1:

D : Seperti apa teknis pelaksanaan pembelajaran daring ketika terjadinya pandemik COVID-19?

M1 : Kegiatan belajar dilakukan di rumah saja menggunakan sistem pembelajaran online

D : Aplikasi apakah yang digunakan dosen untuk melaksanakan kegiatan pembelajaran online?

MI : Setiap dosen menggunakan aplikasi yang berbeda-beda seperti: elearning $U D B$, whasapp, google classroom, telegram, gmeet.

D : Bagaimana pelaksanaan pembelajaran online dengan menggunakan aplikasi yang ada?

M1 : Baik. Tidak buruk
D : Kendala Apa yang dihadapi ketika pembelajaran Online?

M1 : terkadang tidak faham materi yang disampaikan karena sistem yang semakin membosankan. dan Sinyal yang terkadang buruk, kuota yang tibatiba habis.

Sedangkan menurut mahasiswa 2 pembelajaran online dilakukan untuk menyelesaikan perkuliahan yang belum selesai, namun pembelajaran online belum cukup efektif karena penyampaian materi dan pemahaman beberapa mahasiswa kurang memperdalam yang berakibat mahasiswa sulit memahami maksud akan tugas. Karena kendala koneksi internet. Aplikasi yang digunakan tidak berbeda dengan mahasiswa 1

D : Seperti apa teknis pelaksanaan pembelajaran daring ketika terjadinya pandemik COVID-19?

M2 : Terjadi sedikit kendala misalnya susah sinyal walapun begitu Pelaksanaan pembelajaran berjalan dengan baik.

D : Aplikasi apakah yang digunakan dosen untuk melaksanakan kegiatan pembelajaran online?

M2 : Aplikasi yang sering digunakan adalah aplikasi e-learning UDB, zoom, dan WA. Ataupun $e$-mail.

D : Bagaimana pelaksanaan pembelajaran online dengan menggunakan aplikasi yang ada?

M2 : Berjalan dengan baik meskipun dengan sedikit masalah di susah sinyal.

D : Kendala Apa yang dihadapi ketika pembelajaran Online?

M2 : kurang paham materi yang disampaikan karena Susah sinyal.

Pendapat mahasiswa 3 tidak jauh berbeda dengan mahasiswa pertama yaitu pembelajaran online yang dilakukan di Universitas Duta Bangsa Surakarta sudah efektif karena banyak dosen yang memberikan sistem pembelajaran online yang berbeda-beda seperti Zoom, Schoology, Google Classroom dan berbagai jenis aplikasi lainnya, berjalan sesuai dengan jadwal dan juga terencana dengan baik, meskipun terkendala sinyal atau kuota internet dari beberapa mahasiswa 
kendala yang disampaikan mahasiswa 3 sependapat dengan mahasiswa pertama yaitu masalah signal, kuota internet dan situs $E$ learning yang kadang error atau tidak bisa di akses.

Berikut cuplikan wawancara 3:

D : Seperti apa teknis pelaksanaan pembelajaran daring ketika terjadinya pandemik COVID-19?

M3 : Kegiatan pembelajaran berjalan sesuai dengan jadwal, tepat waktu dan terencana dengan baik, meskipun terkendala sinyal atau kuota internet dari beberapa mahasiswa.

D : Aplikasi apakah yang digunakan dosen untuk melaksanakan kegiatan pembelajaran online?

M3 : Menggunakan aplikasi Whatsapp, Zoom, Google meets, dan situs Elearning kampus.

D : Bagaimana pelaksanaan pembelajaran online dengan menggunakan aplikasi yang ada?

M3 : Pelaksanaan pembelajaran berjalan dengan baik, lancar dan juga sesuai dengan yang di harapkan.

D : Kendala Apa yang dihadapi ketika pembelajaran Online?

M3 : Kendalanya antara lain berupa sinyal yang susah, kuota internet yang tidak di miliki oleh beberapa mahasiswa dan situs E-learning yang kadang error atau tidak bisa di akses.

Menurut mahasiswa 4 pembelajaran online dilakukan untuk melanjutkan perkuliahan yang belum selesai, namun pembelajaran online belum cukup efektif karena penyampaian materi dan pemahaman beberapa mahasiswa kurang memperdalam sehingga mahasiswa sulit memahami maksud akan tugas dan tugas yang diterima oleh mahasiswa dalam jumlah banyak. Karena kendala koneksi internet. Aplikasi yang digunakan google meet, google classroom, elearning, group whatsapp schoology.

Berikut cuplikan wawancara 4:

D : Seperti apa teknis pelaksanaan pembelajaran daring ketika terjadinya pandemik COVID-19?
M4 : Selama pandemi Covid-19 ini ada, pembelajaran dilakukan dengan cara sistem jarak jauh menggunakan aplikasi internet maupun sosial media.

D : Aplikasi apakah yang digunakan dosen untuk melaksanakan kegiatan pembelajaran online?

M4 : Aplikasi yang digunakan beragam yaitu google meet, google classroom, e-learning, group whatsapp schoology dan lainnya.

D : Bagaimana pelaksanaan pembelajaran online dengan menggunakan aplikasi yang ada?

M4 : Pembelajaran menggunakan beberapa aplikasi diatas cukup menarik dan praktis.

D : Kendala Apa yang dihadapi ketika pembelajaran Online?

M4 : Ketika sinyal internet kurang stabil dan banyak materi yang kami kurang paham tanpa penjelasan dari dosen serta tugas yang diberikan sangat banyak sekali.

Hasil penelitian berdasarkan angket yang sudah disebarkan terhadap mahasiswa bahwa dampak COVID-19 terhadap kegiatan pembelajaran online di Universitas Duta Bangsa Surakarta adalah terdapat keunggulan dan kekurangan,sebagai sisi keunggulan yaitu dapat berjalan dengan baik, sesuai yang diharapkan, praktis. Kendala yang dialami terdapat pada mahasiswa yaitu masalah koneksi internet, kuota mahasiswa dan aplikasi E-Learning yang digunakan beberapa kali susah diakses. Perkuliahan dilaksanakan secara fleksibel. Aplikasi yang digunakan yaitu E-Learning UDB dan Google Classroom sebagai tempat untuk mengirimkan materi dan Zoom dan whatsapp digunakan untuk mengabsen dan diskusi mahasiswa. Perkuliahan online dilakukan bertujuan untuk menyelesaikan kegiatan pembelajaran yang masih berlangsung. meskipun terjadi kendala koneksi internet pembelajaran tetap berjalan dengan pembelajaran dilaksanakan secara fleksibel.

Hasil wawancara mahasiswa dapat dikatakan bahwa pembelajaran online sebagai salah satu jalur penghubung. pembelajaran 
yang belum usai menjadi salah satu solusi di Universitas Duta Bangsa Surakarta sebagai pengganti kegiatan pembelajaran konvensional atau tatap muka, meskipun terdapat kendala, pembelajaran masih tetap berjalan dengan baik. Aplikasi yang digunakan untuk pembelajaran online yaitu E Learning UDB, E-Mail, Zoom, Google Classroom, whatshapp dan Schoology.

\section{KESIMPULAN}

Berdasarkan hasil penelitian dan pembahasan di atas bahwa dampak COVID-19 terhadap implementasi pembelajaran daring dapat dilakukan dengan baik dan berdampak positif atau efektif dengan artian lebih banyak respon baik daripada kendala-kendala yang dihadapi ketika pembelajaran dilaksanakan. COVID-19 begitu besar dampaknya bagi pendidikan. untuk memutus rantai penularan pandemik COVID-19, pembelajaran yang biasanya dilakukan di ruang perkuliahan sekarang menjadi belajar dirumah dengan menggunakan berbagai fasilitas aplikasi online seperti E Learning UDB, E-Mail, Zoom, Google Classroom, whatshapp dan Schoology. Kegiatan belajar dapat berjalan baik dan efektif. Perkuliahan online berjalan sesuai dengan kreatifitas dari Dosen masing-masing dalam memberikan materi dan soal latihan kepada mahasiswa.

\section{SARAN}

Berdasarkan wawancara penelitian ini, maka terdapat saran untuk memperbaiki pembelajaran online ini untuk semester selanjutnya apabila pembelajaran sepenuhnya dilakukan secara online. Pembelajaran dalam menghadapi pandemi COVID-19 di Universitas Duta Bangsa Surakarta, yaitu dengan memberikan subsidi kuota internet untuk mahasiswa agar kegiatan pembelajaran berjalan dengan lancer karena kuota subsidi yang mereka terima saat ini masih termasuk kurang yang tidak sebanding dengan jumlah tugas yang harus dikerjakan dan mahasiswa tidak mengeluh masalah pembelian kuota yang menjadi terasa berat.

\section{UCAPAN TERIMA KASIH}

Ucapan terimaksih kami sampaikan kepada civitas akademik Universitas Duta Bangsa surakarta Fakultas Hukum dan bisnis dan berbagai pihak yang telah meluangkan waktu, tenaga dan pikiran ditengah pandemik covid 19 yang membantu dalam menyeleseikan jurnal ilmiah ini

\section{DAFTAR PUSTAKA}

Argaheni, N. B. (2020). Sistematik Review: Dampak Perkuliahan Daring Saat Pandemi COVID-10 Terhadap Mahasiswa Indonesia. Placentum Jurnal Ilmiah Kesehatan Dan Aplikasinya, 8(2), 99-108

Arikunto, Suharsimi, Prosedur Penelitian. Jakarta: Rineka Cipta, 2005

Arnesti, N. \& Hamid, A. (2015). Penggunaan Media Pembelajaran Online - Offline Dan Komunikasi Interpersonal Terhadap Hasil Belajar Bahasa Inggris. Jurnal Teknologi Informasi \& Komunikasi Dalam Pendidikan, 2(1). https://doi.org/10.24114/ jtikp.v2i1.3284.

Basori, B. (2017). Efektifitas Komunikasi Pembelajaran Online Dengan Menggunakan Media E-Learning Pada Perkuliahan Body Otomotif. Jurnal Ilmiah Pendidikan Teknik Dan Kejuruan, 7(2), 39-45. https://doi.org/10.20961/jiptek.v7i2.127 22.

Cao, W., Fang, Z., Hou, G., Han, M., Xu, X.Dong, J., \& Zheng, J. (2020). The psychological impact of the COVID-19 epidemic on college students in China. Psychiatry Research, 287, 112934. https://doi.org/10.1016/j.psychres.2020. 112934

Dakwah, S. F., Uin, K., \& Fatah, R.. (2017) Sistem Manajemen Pembelajaran Online, 60-76.

Darmawan, D. (2012). "Pendidikan Teknologi Informasi dan Komunikasi”. Bandung. PT Remaja Rosdakarya.

Ericha Windhiyana Pratiwi.(2020), Dampak $\begin{array}{lllr}\text { Covid-19 } & \text { Terhadap } & \text { Kegiatan } \\ \text { Pembelajaran } & \text { Online } & \text { Di } & \text { Sebuah }\end{array}$ 
Perguruan Tinggi Kristen Di Indonesia, http://doi.org/10.21009/PIP.341.1

Volume 34 Issue 1.

https://beritasumbar.com/dampak-covid-19-

terhadap-pendidikan-nasional/ diakses 16 Mei 2020.

https://beritasumbar.com/dampak-covid-19terhadap-pendidikan-nasional/ diakses 16 Mei 2020

Moleong, Lexy J, Metodologi Penelitian Kualitatif. Bandung: PT. Remaja Rosdakarya. 2010

RI, Peraturan Pemerinatah (PP) No 21 tahun 2020 PSBB

Rizqon Halal Syah Aji (2020), "Dampak Covid-19 pada Pendidikan di Indonesia: Sekolah, Keterampilan, dan Proses Pembelajaran," in SALAM; Jurnal

Rizqon Halal Syah Aji, "Dampak Covid-19 pada Pendidikan di Indonesia: Sekolah, Keterampilan, dan Proses Pembelajaran," SALAM; Jurnal Sosial \& Budaya Syar-I FSH UIN Syarif Hidayatullah Jakarta Vol. 7 No. 5 (2020), pp. 395-402, DOI: 10.15408/sjsbs.v7i5.15314.

S Maudiarti.2018.Penerapan E-learning di Perguruan Tinggi. Jakarta: Gunung Agung http://www.ieee.org/

Wicaksono, S. R. (2012). Kajian Pembelajaran Online Berbasis Wiki Di Lingkup Perguruan Tinggi. Journal of Education and Learning (EduLearn), 6(1), 51. https://doi.org/10.11591/edulearn.

v6i1.190.. 